\title{
USA and the Third World
}

By Knud Erik Svendsen

During the last few years I have been involved in a broad range of policy problems in one particular developing country. My friends in Denmark feel that this has made me too "specific" - too interested in one single tree and not in the wood as a whole. So when they hear - if they hear - that I have accepted to speak on "USA and the Third World" they propably enjoy some badly motivated feelings, followed by sudden worries about what I am going to do to this important topic. This may, in fact, be my main motive in presenting my special version of the English language to this association.

More important is, of course, that we all are forced to be concerned about this major contemporary problem whether we live in USA or another industrialized country or in a low profit developing country in Africa or in more exposed parts of the two other continents of the Third World. What I propose to do is to use the limitations in my background - I am not an expert on global politics, American Society, or on ecology - to raise a number of questions (i.e., to select what I believe to be the more important aspects of the problem and to suggest some answers in order to get inputs from the factors of production which you represent). Knowing something about a few trees, I shall try to speculate about the forest.

As a beginning it might be useful to split the topic into components: the Third World, the USA, their co-presence on this small globe and the flow of time or the dynamics of these components and the structure they form.

First of all, I am not sure that it makes too much sense to speak of a Third World, or the developing countries as a homogenous group of states. The understandable preference of international organisations to generalize often leads to serious loss in individuality 
of the many countries in Africa, Asia and Latin America. There is a common denominator of a low level of material living, short average length of life and so on, a commonness of poverty, but there are also enormous differences. Let me just mention the six most populous of the countries - according to a rather outdated usage the People's Republic of China belongs to the second world - they are: India, Pakistan, Indonesia, Brazil, Nigeria and Mexico. Of course there are common features, also in their relations with USA, but in their present situation and in their recent history there are also great differences. This diversity is perhaps most distinct in the sphere of politics. And I sometimes wonder whether the tendency of large bureaucracies to globalize by speaking about the developing country does not lead to a neglect of political factors. If I throw in a few other names of developing countries you may understand what I mean: the Philippines, Cuba, the Dominican Republic, Congo, Algeria and Vietnam.

We have the same problem of diversity when we look at the second component: the USA. Maybe the Americans and the rest of us had a reasonably clear picture of what. USA meant ten years ago - I said maybe - today very little of the Great American Celebration is left. There is a process of decelebration raising fundamental questions about state, society and individual far outside the New Left, which by the way did not exist a decade ago. In this diversity we must look for some pattern or maybe several patterns.

Then there are the effects of the presence of an inhabitant like the USA in what has been called spaceship earth. The USA is very big in terms of production - it produces roughly half of the output of the Western countries - but this is only a part of the problem. USA is a changing structure, propelled along by strong material and technological forces, it is also a conglomerate of many strong short and long run interests, it is a state with rulers who think in terms of role, leadership and commitments in the World. How does this affect the countries in Africa, Asia and Latin America and how important are these countries: or some of them to the USA?

All these grand questions we have to combine with a sense of time. A rewriting of history is taking place to such an extent that I understand that one speaks of a revisionist school in the USA.
A number of international organisations have during the last two years tried to assess the performance of the developing countries in the sixties and to think ahead in development decades. First of January this year began the Second Development Decade or as it with an unfortunate abbreviation is called: the DD2.

The rethorics of the declaration on the second decade show that there has been a shift in the understanding of the development problem in the last ten years. The sixties began with growth as the dominant concern, even expressed in a growth target for the developing countries. At that time there was also a fashionable theory of stages - presented by an American historian later to become advisor to a president - arguing for a sequence for all countries leading to the stage of happy mass consumption, i.e. the USA of the fifties. This approach will have little chance to gain similar publicity today after a decade of learning which has brought if not ready answers to major problems then at least greater modesty.

The goals of development policies are now defined much more broadly and while many at that time were ready to accept growing economic and social inequality as a necessary companion of growth, then most nowadays are ready to agree that this may create serious internal problems. This concern may be just a concession to reality, i.e. to experiences of social turmoil as a result of a one-sided growth process. The Harvard people were taught this lesson in Pakistan. It may be a dislike of too much inequality as when the UN resolution on the second decade with a strange choice of words says: "If undue privileges, extremes of wealth and social injustices persist, then development fails in its essential purpose." One may ask: What are due privileges? Or it may be a more straightforward advocacy of social revolution. In any case few will today accept and state that a sustained increase in material production in itself will solve the problem of the poor countries.

There is also much greater understanding of the difficulty of developing the developing countries. Many liberal advocates of increased foreign assistance - e.g. Lester Pearson's Commission on International Development - have counteracted a widespread disillusionment around the results of assistance, to be found in particular in USA, by describing the performance of the sixties in excessivly optimistic terms. They could have limited themselves to the statement 
that many of the expectations to the effect of a very small transfer of resources were completely wild. But apparently public optimism is understood to be better than public realism as an appeal for further aid.

There was a lot of instability in the Third World in the sixties, but very few cases of outright chaos. And the overall growth target of an annual increase in total production of 5 per cent was reached for the group of countries as a whole but not for the majority of its populations.

Still the major lesson has been the difficulty of the task and a growing acceptance of the multi-dimensional nature of the process.

I am afraid, however, that very few have followed this line of thinking through to its logical conclusion. Too many speak as if closing the gap between the poor and the rich countries is a practical proposition. This is really to hope for some kind of miracle or to resist to recognize the size of the gap or the extreme distortion of the living conditions on the globe produced in the past two-three centuries.

If the present rates of the growth continue Latin America will at the end of the century have reached the present average income of the developed countries and Africa and Asia will have obtained the present Latin America level. In the meantime, the centers of technological innovation i.e. the developed countries, will grow even more and the gap in absolute and relative terms will have increased.

One can discuss the details of the assumptions but I believe that the conclusion will stand that it makes no sense to expect the developing countries to copy the present forms of material living in the industrialized countries. There are good reasons to discuss whether such an imitation is desirable. Everything seems to show that it is not possible.

A reflection on the roots of underdevelopment may perhaps remove a little of the blind faith in developmentalism. There is growing acceptance of the fact that some countries are poor because some other countries are rich, or that world economic system limits development and underdevelopment. The distortion has gone so far that there is little chance of removing it. And up till now and probably through the 70 's the spread effect of the rich countries of the West will be negative if the present international economic order is not radically changed. I shall expand this point a little later.

Developing countries must, therefore, look for other ways of increasing human happiness. A development policy must aim at other than only material things. President Nyerere has said "Other nations aim at the moon, we must aim at the village." One could add that the aim must be - from the beginning - the quality of life. And this aim must take the form of viable social units at low levels of income. This calls for a much wider approach to technology than we are used to.

It also raises the issue of equality and inequality. Viable social units of the nature just discussed are probably not possible with large degrees of inequality, so equality for that reason becomes a development objective. But is this not utopian in the sense that most of what we have seen in the Third World produces inequality?

A report on Poverty in India prepared by the Indian School of Political Economy, under a contract from the Ford Foundation was published in January this year. It concluded that during the past decade per capita consumer expenditure increased by less than half a per cent per year. Moreover the small gains have not been equitably distributed among all sections of the population. The study believes that a deliberate policy to ensure an equitable distribution of the gains of development is possible, without accepting communism as a classical solution to the problem of poverty. But the belief rests on the hope - to quote - that the rich, the vested interests and the policy makers who represent them will see the point. If not...

This is not only India's problem. Latin American countries have had this conflict of interests much longer. President Nixon gave it a special twist in his report on U.S.-Foreign Policy for the 1970's, February this year where it is stated "Efforts to reconcile the often conflicting demands of social reform and economic growth and to meet the need for popular support, have spawned statist, sometimes radical, approaches." To this, more and more Latin Americans will say that it is not possible to get economic growth without social reform and mass participation. There may be a choice in the short run, but not in the long run.

It is a central question what American Policy makers think about 
this ferment in the Third World. And Latin America provides many examples of their temporary solutions to this problem. Intervention, support of reformists à la Frei, freezing of Quadros and Goulart followed by assistance to the military regime in Brazil. If there is any consistency in the American approach to this changing situation then it is a reduction in the use of economic assistance and a change from traditional military assistance to technical assistance in counterinsurgency efforts. This was called by the then Secretary of Defence. Robert S. McNamara in his report to Congress in February, 1968 to reorient "the military policy to bring it into line with the nature and scope of the real threat."

Whether one believes that the developing countries are ripe for revolution or not it is obvious that many of these countries because of their internal politico-economic structure and the tensions between expectations and possibilities each in its own way will experience revolutionary situations where one or another form of politics may take command.

Instead of asking straight-away about USA's interests in these matters we should rather ask the question how the American development situation in the past and present influences the American ability to perceive the true nature of the situation in the three continents. USA is more than one of the super-powers, it also represents a specific social system in a specific geographical and resource setting.

As such the American development history is probably the most special case of all. An extremely advantageous resource position both in terms of land, capital and men has been combined with a similarly advantageous security position far away from the European theater. The second war restored and pushed the economy ahead after a severe crisis and the result has become the highest statistical level of living. With the knowledge we now have of other development cases it is or ought to be very obvious that this American statistical success is very exceptional, that USA cannot be imitated.

And the sixties beginning with top-level concern about the military-industrial complex have produced a large amount of new thinking on the trends of American social and economic development. This heartsearching has penetrated official rethorics in the second half of the sixties setting new and different goals for the future.
In a statement on the economic policy issues for the 1970's the O.E.C.D. last year called for a better direction of the growth process so that the extra wealth is used to meet the needs and wants of society and the damaging side effects of growth are prevented. And the major policy goals are said to be the alleviation of poverty, the provision of acceptable housing standards, the elimination of hazards to health, the improvement of environment. Some analysts are discovering that USA is in fact three forms of life in one country: a pre-industrial, an industrial and a post-industrial civilization.

The American self-image is clearly being eroded. But is it possible to discover a "law of motion" of Modern American society, to trace leading factors and resulting trends in USA? Foreign policy, including US policy towards the Third World, may respond with some time lag to internal changes in the USA, but it still seems to be sensible to accept some form of link between domestic and external affairs. Many statesmen in the Third World are asking the question: what will happen to the USA in the seventies, maybe without the condescending tone which dominates much American comment on "instability" in Black Africa.

The high degree of political unrest in USA in the last few years makes it very difficult to form an opinion on what will happen. The outcome will depend upon various objective factors, but also on the subjective reactions to the situation. And some of the problems which American politics face these years are new to the system - even if some of them have been known for long in Europe, to use the condescending tone of a Scandinavian - so that the USA in its own terms is on a social or socialpsychological frontier which makes prediction very difficult.

It may still be useful to consider some of the major components in the sitiuation. To me as a political economist they seem to be: an economic system based on large privately controlled corporations, a growing participation of general government in economic life and a military sector larger and more active than ever before in American history. At the same time there is a high rate of technological development, stimulated if not dependent on military and space programmes. And a scene of groups or social stratification or class formation with new actors like the students, the black Americans, and those who resist the war in Vietnam. 
Short of an international monetary disaster very few would spend time on discussing the possibility of a major economic setback, provided that USA can learn to live with inflation. But there are still serious economic problems such as unemployment, hitting the young and among them especially the black, and the major problem of performing in terms of public consumption. Capacity to produce commodities will keep on growing, but the problem of using this capacity is worrying many more than Marxists like Baran and Sweezy. In fact, the most interesting about their important book "Monopoly Capital" is the reaction of other Marxists to their theses that the present system can only dispose of the rising surplus through the military and that it can only be changed through a revolution coming from the villages of the world, i.e. the developing countries.

Other Marxists expressed a belief in the ability of the American system to adapt to the needs for social reform also because they thought that Baran and Sweezy were wrong in discarding the American working class as being bribed with increasing private consumption. Some of the problems faced by USA have been solved by other countries with capitalist systems of production through social reforms, so why could this not happen in USA - these other Marxists seem to ask.

On the domestic scene the American government as representing a form of general interests : - as opposed to the interests of individual giant corporations - are squarely faced with the need to handle urgent social problems. The effects of the war in Vietnam on American society have emphasized this, even if they are still working their way into the American mind. The rich and powerful American system has not found a feasible method to win a war in a small developing country, the high material and human costs (to USA) are being understood. Not only the conscience of many Americans, but also their self-confidence has been affected.

Another American analyst of a different kind, namely $Z$. Brzezinski wrote in his book "Between Two Ages" that to-day in the Third World a subjective revolution is preceding change in the objective environment and creating a state of unrest, uneasiness, anger, anguish, and outrage. His analysis of USA might have been less dominated by the marvels of technology, if he had known that many in the Third World think that USA is in the same position.
Perhaps the most difficult factor to predict is the behaviour of the military sector. Many of us are used to be worried about the army leaderships in developing countries, because of their strength in weak political systems. The relative strength of the military complex has grown steadily in USA in recent years. On the other hand the pay-off of the military expenditures has been doubtful and army court cases of recent months have shown how labile the attitudes towards the military are, following an unsuccessful war.

All this is part of the background for our thinking on the relationship between USA and the Third World. We have to ask how the interests of the expanding American corporations affect the Third World, what the general economic interests of USA vis à vis the developing countries are, how the American military look on the Third World, how the leaders perceive US interests as a superpower and all of this in a situation where the American scene is in a state of flux.

The Third World is as a sphere of investment for American corporations. This presence of foreign controlled assets create a number of problems. The Latin American countries have been the first to witness that it is far from true that what is good for the American corporations is good for the World. Celso Furtado who was a leading economist in Brazil before the military dictatorship, said in a study published last year that the large firms with their advanced technology and high degree of capital intensity have the same effects on an underdeveloped economy - especially when they are supported by many privileges - as certain large exotic trees brought into new areas: they drain off all the water and they dry out the land and thereby create an ecological unbalance that permits the emergence of diseases and plagues. According to Furtado the hegemony which the United States exercises in Latin America constitutes a serious obstacle to the development of the majority of the countries in the region since it reinforces the anachronistic power structures. The foreign-aid strategy of the US Government which creates privileges for large corporations and which exercises preventive control of "subversion", contributes to the preservation of the most retrograde means of social organisation. And it tends to negate the effectiveness of the national states as decision-making 
centers and as instruments for the mobilization of societies to undertake the tasks of development.

The economic presence of USA in other countries may not be as strong as in Latin America, but the efforts to export the American corporate system are the same. Why are so many governments so cooperative in this matter? A few of them because they feel confident that they can control the foreign corporations, others because they only see the immediate effects of foreign investments, and others again because the leading strata in the countries benefit from such a policy at the expense of the overall development of the economies of their countries.

On the whole the US Governments have supported this general emphasis on private investments and President Nixon has recently stressed it in his foreign aid statements. It is a policy which creates decision-making problems for the USA in a number of countries, partly because the strategy does not seem to be effective in promoting internal, if only lopsided development in the countries, partly because it is met with national resistance in an increasing number of countries. The Third World at this moment watches the US behaviour towards countries like Chile and Peru, ten years after the attempted invasion of Cuba.

The Third World is important to the U.S. economy not only as a sphere of investment and trade for American corporations, but also as an important supplier of raw materials. For quite a number of important materials the USA - contrary to what many think depends on materials from a few developing countries. This has been amply demonstrated by Harry Magdoff in his study "The Age of Imperialism". What this fact of nature means to the American economy is another matter. It is clear that uncontrolled American corporations will attempt to control the sources of supply, but it is not certain that they can be checked only by a complete change in the American system. A more concerted effort from governments in developing countries may lead to higher prices on these particular materials. Interests in the USA will, of course, try to use the US government against such efforts. It should be added that far from all - and few of the most populous -- countries in the Third World are in this position of suppliers of important raw materials.

The USA, however, does not perceive its role just in terms of specific economic interests in particular countries. There are too many signs that the American leadership have a much broader notion of its role or commitment based not only on its position as a superpower vis à vis two other superpowers, but also on its ideas on how the countries except those already "lost to communism" ought to manage their affairs. The Third World is not alone with the USA on this globe but it is still exposed to the effects of the US perception of its leadership roles. The Nixon doctrine has not changed this - at least as I have been able to study it from Dar es Salaam. In the already mentioned February report to Congress President Nixon says that the greater share in the definition of policy as well as in bearing the costs of programs requiers to qoute "a new, more subtle form of leadership" and "a more efficient and a less conspicuous approach". And he warns against "nascent isolationism in reaction to overextension".

The major problem of US foreign policy as seen from the Third World is, therefore, not only its active efforts "to contain communism" as the consequence of the activities of the other superpowers. It is also and rather the continued fear of American leaders of real social changes leading to parterns of development which if not communist at least question many of the values of the American establishment.

In Africa, which I know best, more and more politically interested people are becoming interested in Latin American matters, less and less because of Cuba and its - mixed -- experience, but more because of the changes in other countries. The lesson that the 1960's taught the U.S. Government in Latin America - to speak with the historian Eric Hobsbawn - (as they did more dramatically in Vietnam) is that there are severe limits to the power of even the biggest, richest and most megatoned imperial ruler.

Personally, I hope that such a better sense of proportion with regard to the official USA will pay the way to a better understanding in the Third World of unofficial USA and its efforts to develop values of a kind which can bring hope and friendship similar to efforts of some developing countries whether they are ranked in the Second or the Third World. 